\title{
Cram Schools in Japan: The Need for Research
}

\section{Robert J. Lowe}

\author{
Rikkyo University
}

\begin{abstract}
The private juku (cram school) industry is an enormously profitable and influential area of education in Japan, including in the specific field of English language teaching (ELT). However while much research has been carried out in other areas of ELT in Japan, juku have largely escaped the attention of researchers. This paper attempts to argue the need for more research into English language education as it is practiced in juku. The article first situates juku within the Japanese education system, and then illustrates the extent to which juku have been under-researched when compared to other ELT contexts in Japan. The author advocates the need for more research into ELT to be carried out in juku, and finally suggests some areas into which this research could be conducted.
\end{abstract}

学習塾産業は大きなビジネスであり、日本の英語教育に大きな影響を 与えている。ところが、高校や大学などでの英語教育に関する研究は多く なされているが、学習塾での英語教育の研究はされていない。本論では、 初めに、学習塾の現状を説明し、次に、どれだけ学習塾の英語教育の研 究が不足しているか説明する。最後に、学習塾の英語教育の研究の必要 性を訴え、より多くの研究がこの分野で行われるべきであると論じる。

nglish language teaching in Japan is carried out in many different contexts. Mandatory English education takes place for all children from elementary school to the end of high school, and in addition, students who continue to study at the tertiary level are often expected to complete courses of foreign language education. Alongside the state school and tertiary educational systems, there is also a large private market for English language education, which manifests in many different types of institutions; two of the most common being eikaiwa (English conversation schools) and juku (cram schools). English is not the only subject taught in juku, as they are cram schools designed to help students cram for exams and get into universities, and so they teach many different subjects (maths, Japanese, etc.) However, as I shall demonstrate below, English is a very commonly taught subject.

English education in Japanese elementary schools, high schools, junior colleges, and universities has been the subject of considerable amounts of research. Studies have been carried out in these contexts regarding educational policy (see Hashimoto, 2009; Yonezawa, Akiba, \& Hiouchi, 2009), teaching methodologies (see Gorsuch, 2001; Nishino \& Watanabe, 2008), classroom policies on language use (see Hashimoto, 2013; Yphantides, 2013), teaching materials (see Yamanaka, 2006; Mineshima, 2008; Sano, lida, \& Harvey, 2009), teacher and student perspectives (see O'Donnell, 2008; McKenzie, 2008; Rudolph and Igarashi, 2012), teacher identities (see Butler, 2007; Nagatomo, 2012) and many other areas. As a result, much is known about English education in these settings, providing views on each context at different magnifications, from the overall structure of the institution to the details of classroom teaching and interaction. The eikaiwa sector has not drawn as much academic interest, but still a substantial body of research exists concerning the motivations of eikaiwa students (Seargeant, 2009; Kubota, 2011), the professionalism of schools (Bossaer, 2003), the professional lives of teachers (Nagatomo, 2013) and the ideologies surrounding the industry (Seargeant, 2009).

Despite the intense interest in English language education in Japan, however, the private juku sector has not been subject to nearly the same level of scrutiny as either the state school, tertiary sector, or the private eikaiwa industry. In this article, I will attempt to make the case that more research needs to be carried out into ELT in juku schools. I will discuss the prevalence and importance of juku schools, analyse the amount of research carried out when compared to other sectors of ELT in Japan, and discuss some of the possible reasons for juku being under-researched. Finally, I will suggest some areas in which research could be conducted.

\section{Juku: Context, Prevalence, and Importance}

Bray (2007) uses the term shadow education to describe the unregulated global industry of private 
tutoring, and notes that in the context of Japan juku are by far the most common and popular form of this. Juku are private cram schools, in which teaching takes place on many different subjects either one-to-one or in small classes. Most juku teaching is carried out after school hours for the purposes of supplementing the students' education and providing support for students in preparation for their university entrance exams. Juku are not licensed as schools and Iwata (2006) notes that because of this "the teaching staffs [sic] in juku schools need no license" (p. 2). This means that juku teachers are usually not trained or qualified, although some juku teachers may be postgraduate students with teaching qualifications. Indeed, many juku teachers are university students themselves, hired part-time for reasons of cost-saving and because they are familiar with the university entrance exams for which the students are preparing. Therefore, there is no official or external oversight of any aspect of juku, be it in terms of teaching methodology, teaching materials, or anything else. This is a particularly jarring revelation when considering the prevalence of juku in Japan.

The juku sector is very large, and very influential. Dierkes (2008; 2010; Cited in Cook, 2013, p. 403.) has claimed that there are roughly 50,000 juku in Japan, and Pettersen (1993) and Roesgaard (2006) have both noted that the juku business brings in billions of yen in profits each year. These high figures are explained by the large customer base to which juku cater. Bray and Lykins (2012) state that $15.9 \%$ of elementary school children in Japan attend juku, and the levels of attendance gradually increase to the point where, in the third year of junior high school, $62.5 \%$ of students are regularly attending juku for tutoring after school (cited in Cook, 2013, p.403). Bray (2007) notes that roughly $70 \%$ of all Japanese students will attend juku at some point of their school life, and that this number has increased dramatically over the past few decades; more than doubling between 1976 and 1993 (p. 23). The increase in student attendance between elementary school and senior high school can largely be attributed to the wish to perform well on university entrance exams. While students may be concerned with studying various subject areas, depending on the course they wish to enter, Gilfert (1999) notes that most university faculties include English as a required subject. This makes English one of the most commonly taught subjects in juku.

It is clear that there is a huge amount of students studying English in juku, largely for the purpose of improving their university entrance exam scores, and sometimes just to improve their knowledge of the language (O'Donnell, 2003). It is therefore surprising that, as I shall demonstrate in the following section, juku are generally under-researched.

\section{Research into Juku}

Bray (2007) notes that globally, private education is a huge business, but one "which so far has received little attention by researchers" (p. 18). Similarly, despite the prominence of juku, there has been very little research into them, particularly from ELT researchers.

It is not the case that no research into juku exists at all. Indeed, a small number of papers and books have been published. However, these studies are from fields as far apart as psychology (O'Neil and Fukumura, 1992) and Japanese studies (Rohlen, 1980), with many focusing on Japanese education or general education (Harnisch, 1994; Russel, 1997; Roesgaard, 2006). These pieces of research have great value in terms of putting the juku system in context, and analyzing its social status and utility. However, there are very few articles which focus directly on ELT, which is surprising given: a) the amount of English taught in juku, and b) the level of research carried out in other ELT contexts in Japan.

Of those papers which do focus on ELT, a handful of studies have been published exploring things such as methodology, student experiences, and teaching materials. Takigawa (2005) investigated the effects of communicative tasks on grammatical form uptake in juku schools, finding evidence that the adoption of communicative methodologies in juku could help improve students' language skills. Lieske (2004) looked at attitudes towards English among university students who had previously attended juku, concluding that they do not have a detrimental effect on attitudes towards English. O'Donnell (2003) found that students differ in the reasons given for attending juku, with some attending purely to pass exams, and some seeking to improve their overall English proficiency. Lowe (2013) analysed juku teaching materials in terms of gender representations, concluding that they featured problematic and stereotypical representations of females. It seems from this research that there are several areas of study into juku schools that could be informative and useful. However, in the ELT literature juku are very rarely mentioned in any context other than their relationship to university entrance exams. Despite the research potential of juku, in the next section I will provide some data to highlight the extent to which juku have been under-represented in ELT research when compared to other educational contexts in Japan. 


\section{The Scale of the Problem}

In order to illustrate the extent to which research into English education in juku has been neglected, this section presents some data comparing the amount of published research on juku to the other sectors discussed earlier; elementary school, high school, university/junior college, and eikaiwa.

This data was collected from the Japan Association of Language Teaching (JALT) publications archive. The purpose of collecting this data was to illustrate the point made in this article - that juku are comparatively under researched - rather than to provide solid figures on the total amount of ELT research carried out in each of these sectors. As such, I chose to focus on one organisation which I felt would be most likely to represent the balance of research in the field. JALT is the largest language teaching organization in Japan, and therefore data taken from JALT publications is likely to be representative of the major concerns of researchers in the country. Similarly, I chose to focus on the largest research publication in the organization, the JALT Journal, as I felt this would give a representative sample of research that has been produced in the Japanese context. JALT was chosen over other large language teaching organisations in Japan such as the Japan Association of College English Teachers (JACET), because these organisations have a specific institutional research focus (colleges and universities in the case of JACET).

Papers were analysed from all issues of the JALT Journal between 1979 and 2014, and were classified into five categories based on the context in which the research was carried out: elementary school, high school, university/junior college, eikaiwa (usually referred to as some variation of private schools for adults in the literature), and juku. Universities and junior colleges were combined into one category as they are both post-secondary institutions. A paper was considered to belong to these categories if it focused on any of the following areas of the context in question: participants (either teachers or students), materials, methodology, assessment, motivation, policy, or instructional principles. Papers which discussed two or more contexts (as in a comparative study) were counted in both categories. In order to avoid ambiguity, studies were not included in the category if they took place outside of Japan, such as university students studying abroad. The data is presented in Table 1 .

From this it is clear that, when compared to other areas of research interest, juku have received almost no attention from researchers in the field of ELT. Universities, junior colleges, and high schools have all been significantly researched over the past three and a half decades, with university-based research being by far the most prominent. Eikaiwa have received only a little attention, with three pieces of research being carried out. Elementary schools are also under-represented; however this is probably due to the fact that elementary schools only recently began to feature mandatory English education. While elementary schools and eikaiwa received only a small percentage of research attention, they still featured more in the literature than juku, which were only prominently featured in one piece of research, and even this research was largely about the attitudes of university students towards English (O'Donnell, 2003). The point of this analysis was not to claim that no research into juku exists in the field of ELT at all-as described earlier, a few papers have been published on the topic-however it does show that juku are underrepresented when compared to other contexts in Japan in which English education is taking place. In the next section I will propose and discuss some of the reasons why this may be the case.

Table 1. Papers Published in Different Contexts in the JALT Journal

\begin{tabular}{ccccc}
\hline $\begin{array}{c}\text { Elementary } \\
\text { School }\end{array}$ & $\begin{array}{c}\text { High } \\
\text { School }\end{array}$ & $\begin{array}{c}\text { University/ } \\
\text { Junior } \\
\text { college }\end{array}$ & Eikaiwa & Juku \\
\hline 5 & 42 & 83 & 3 & 1 \\
\hline
\end{tabular}

\section{Why No Research?}

There are several reasons why research may not have been carried out in juku. I shall provide some of these reasons below and, where necessary, argue why these objections are not valid.

\section{Researchers Do Not Work in Juku}

It is often the case that researchers focus on contexts which are easily accessible to them, and most researchers are employed at universities. This seems like one likely explanation for the fact that the balance of research tilts strongly towards universities. This is certainly a good explanation for why juku have largely escaped the attention of researchers; however this fact does not provide any reason why research should not be carried out in juku schools.

\section{Juku Are Difficult to Access}

Unlike state schools and universities which are often open to having research carried out in them, juku are private businesses which are not licensed nor subject to professional oversight. As such, they 
may be resistant to having research carried out by people from outside of the company, as they may feel there is little benefit to doing so, or that the presence of researchers may actively disrupt or negatively represent their business. This problem may also be echoed in the concerns of parents, who could object to their children being the subjects of research and raise concerns about privacy and about strangers carrying out research with minors. These are serious concerns, and could cause difficulties for researchers trying to access juku for research purposes. However, these difficulties are similar to those encountered in much of the social science research, and making the effort to seek permission to conduct research in juku may provide rewarding new knowledge.

\section{Juku Are Designed Only for Exam Preparation}

With two major practical concerns already discussed, a final reason for the under-researching of juku may be a lack of motivation on the part of researchers to investigate these institutions. Researchers may feel that juku have a limited educational role-to serve as supplementary to regular education and aid students in passing their university entrance exams. As such, research into these schools would be limited and there would be less opportunity for researchers to pursue their own research interests than in other settings. This seems to be a good reason as to why these schools have not have been heavily featured in research.

However, this ignores the possible benefits that such research could have. As discussed earlier in this paper, research into juku has produced interesting and promising results in the areas of methodology (Takigawa, 2005), student perceptions (Lieske, 2004), and materials design (Lowe, 2013). More research carried out in the context of juku schools could help to improve the learning environment of these schools for students, and help them achieve their learning goals even if their learning goals are limited to exam preparation. In addition, research by O'Donnell (2003) suggested that many students attend juku in order to improve their English proficiency rather than just to pass exams, and as such there may be more opportunity for improvement in teaching and learning than is readily apparent.

It is possible that research into juku would not necessarily lead to changes in practice or to an uptake in recommendations by the schools in question. This would not be unusual, as there is rarely a clear and direct path by which research leads to better practice. However, this does not reduce the fact that research into juku has the potential to generate valuable and important insights and knowledge.
While the reasons outlined above help us to understand why there is currently a lack of research into juku, and identify some of the possible challenges of carrying out such research, they do not seem to provide a serious rationale for not carrying out such research in the future. In the next section I will discuss some of the possible paths future research may take.

\section{Future Directions for Research}

In the sections above, I have made a case for more ELT research being carried out in the juku. The question remains, however, of what form this research may take. When considering this question it would be instructive to look at the kind of research carried out in other contexts in Japan. In the introduction to this paper, I noted some areas which research has focused on in other contexts. In the following section I shall suggest which would be useful to research in juku, and provide some commentary explaining these choices. I believe that four key areas for juku research to investigate are:

- methodology

- teacher education and training

- teaching materials

- $\quad$ student and teacher perspectives

As research from Takigawa (2005) has hinted, studies into the methodology used in juku may be instrumental in increasing the effectiveness of teaching and retention of information among students. While the learning aims of these schools may be limited, research into methodology and classroom instruction could help students to achieve these aims more successfully, and thus be a valuable area of research.

As noted earlier, most teachers working in juku are not trained or licensed, and so their approaches to teaching may not reflect current trends in classroom practice. A focus on how teachers are prepared by their schools (if at all) would be interesting, and may help to inform in-service teacher education.

A study by Lowe (2013) found evidence of problematic gender bias in materials used in a juku. More research into this area would be needed to discover if this kind of issue is widespread, but it would certainly be of interest to researchers if potentially problematic material was being used during English education in juku.

As juku are focused largely (though not solely) on the teaching of grammar for the purposes of passing university entrance exams, there is a possibility that this may contribute to students having negative 
attitudes towards future language study. Negative experiences have been shown to influence negative future attitudes towards language study (Kimura, Nakata, and Okumura, 2001), and therefore research into whether this was the case would be extremely helpful.

These are some possible areas that research into juku could focus on. However, it is possible that more avenues of research could open in the future. These preliminary suggestions should at least provide some directions for initial research and pilot studies to take.

\section{Conclusion}

In this paper I have argued the need for more research into ELT in juku. I have reviewed the literature showing that juku are extremely prevalent in Japan, with roughly $70 \%$ of Japanese children attending them during their schooling. I have also argued that many, if not most, of these children will study English in juku. Despite the prominence of the the industry, I have demonstrated that juku are underrepresented in ELT research in Japan, and discussed some of the possible reasons for this. Finally, I have laid out some areas that research into juku could take.

As an industry which is such a prominent part of English education in Japan, it is surprising that so little research has been carried out into juku, and I hope this paper has gone some way toward demonstrating the need for more research into this context to be produced in the future.

\section{Acknowledgements}

I would like to thank Guy D. Middleton and Amanda Chin for their help with early drafts of this article. I would also like to thank Asae Takizawa for her assistance with translations.

\section{References}

Bossaer, A. (2003) The power of perceptions: A look at professionalism in private language schools in Japan. JALT Hokkaido Journal, 7. 13-23.

Butler, Y. G. (2007) Factors associated with the notion that native speakers are the ideal language teachers: An examination of elementary school teachers in Japan. JALT Journal, 29(1), 7-40.

Bray, M. (2007). The shadow education system: Private tutoring and its implications for planners (2nd Edition). Paris; UNESCO. Retrieved on September $18^{\text {th }} 2013$, from $<$ http://unesdoc.unesco.org/images/0011/001184/118486e.pdf>
Bray, M., \& Lykins, C. (2012). Shadow education: Private supplementary tutoring and its implications for policy makers in Asia (Vol.9). Philippines; Asian Development Bank.

Cook, M. (2013). Expatriate parents and supplementary education in Japan: Survival strategy or acculturation strategy. Asia Pacific Education Review, 14(3), 403-417.

Dierkes, J. (2008). Single-sex education in the Japanese supplementary education industry. Paper presented at the Comparative and international educational society. New York, NY.

Dierkes, J. (2010) Teaching in the Shadow: Operators of small shadow education institutions in Japan. Asia-Pacific Educational Review, 11(1), 25-35.

Gilfert, S. (1999) Let's write in English: Teacher, we never learned that. The Internet TESL Journal 5(1). Retrieved from <http://iteslj.org/Articles/Gilfert-LetsWrite.html>

Gorsuch, G. (2001) Japanese EFL Teachers' perceptions of communicative, audiolingual and yakudoku activities: The plan versus the reality. Education Policy Analysis Archives, 9(10), 1-27.

Harnisch, D. L. (1994) Supplemental education in Japan: Juku schooling and its implication. Journal of Curriculum Studies, 26(3), 323-334.

Hashimoto, K. (2009) Cultivating "Japanese who can use English": Problems and contradictions in government policy. Asian Studies Review, 33, 21-42.

Hashimoto, K. (2013) 'English-only', but not a medium-of-instruction policy: The Japanese way of internationalizing education for both domestic and overseas students. Current Issues in Language Planning, 14(1), 16-33.

Iwata, Y. (2006). Teacher education and neo-liberalism-Japan and other countries. Key presentation at round-table session at 2 nd international conference of teacher education. Given on 27th October 2006 at East China Normal University, Shanghai. Retrieved from <https://www.u-gakugei.ac.jp/ currict/about/iwata. info/20061027shanghai.pdf>

Kimura, Y., Nakata, Y., \& Okumura, T. (2001) Language learning motivation of EFL learners in Japan: A cross sectional analysis of various learning milieus. JALT Journal, 35(1), 47-68

Kubota, R. (2011) Learning a foreign language as leisure and consumption: Enjoyment, desire, and the business of eikaiwa. International Journal of Bilingual Education and Bilingualism, 14(4), 473-488.

Lieske, C. (2004) Attitudes towards English: A comparative study of first-year students at tertiary institutions. Bulletin of Shimane Nursing College, 9, 83-90.

Lowe, R. (2013). Wolves in sheep's clothing: Gender representations in authentic EFL vocabulary texts. The Journal and Proceedings of the Gender Awareness in Language Education SIG, 6. 6-26. 
McKenzie, R.M. (2013) Explicit and implicit attitudes of the Japanese university student towards variation in L1 \& L2 English speech: The sociolinguistics of the internationalization of Higher Education in Japan. The Japanese Society For Language Sciences Conference Handbook 2013. Retrieved from: <http://lecture.ecc.u-tokyo. ac.jp/ cwpgally/references/JSLS2013-McKenzie.pdf>

Mineshima, M. (2008) Gender representations in an EFL textbook. Bulletin of Niigata Institute of Technology, 13, 121-140.

Nagatomo, D. H. (2012) Exploring Japanese university teachers' professional identity. Bristol: Multilingual Matters.

Nagatomo, D. H. (2013) The advantages and disadvantages faced by housewife English teachers in the cottage industry eikaiwa business. The Language Teacher, 37(1), 3-7.

Nishino, T. \& Watanabe, M. (2008) Communication-oriented policies versus classroom realities in Japan. TESOL Quarterly, 42(1), 133-138.

O’Donnell, K. (2003) Uncovering first students' language learning experiences, their attitudes, and motivations in a context of change at the tertiary level of education. JALT Journal, 25(1), 31-62.

O’Donnell, K. (2008) Japanese secondary English teachers: Negotiation of educational roles in the face of curricular reform. Language, Culture and Curriculum, 18(3), 300-315.

O’Neil, H. F. \& Fukumura, T. (1992) Relationship of worry and emotionality to test performance in a juku environment. Anxiety, Stress, and Coping: An International Journal, 5(3), 241-251.

Pettersen, L. (1993). Japan's “cram schools". Educational Leadership, 50(5), 56-58.

Roesgaard, M.H. (2006). Japanese education and the cram school business. Copenhagen: NIAS Press.

Rohlen, T. P. (1980) The juku phenomenon: An exploratory essay. Journal of Japanese Studies, 6(2), 207-242.

Rudolph, N. \& Igarashi, Y. (2012) Conceptualizing the role of the English language teacher within and beyond the native speaker construct: A focus on Japan. The Asian Conference on Language Learning 2012 Official Conference Proceedings (pp. 342-352). Osaka: Japan.

Russell, N. K. (1997) Lessons from Japanese cram schools. In W. K. Cummings \& P. G. Altback (Eds.), The Challenge of Eastern Asian Education: Implications for America (pp. 153-172). New York: State University of New York Press.

Sano, F., lida, M., \& Hardy, T. (2001). Gender representation in Japanese EFL textbooks. In M. R. Swanson \& D. McMurray (Eds.), PAC3 at JALT 2001 Conference Proceedings (pp. 900-906). Tokyo: JALT.

Seargeant, P. (2009) The Idea of English in Japan: Ideology and the evolution of a global language. Bristol: Multilingual Matters.
Takigawa, Y. (2005) Communicative task and its effect: Focus on form activity on the third person singular agreement at a cram school in Japan. Bulletin of Osaka Jyogakuin University, 2, 25-31.

Yamanaka, N. (2006) An evaluation of English textbooks in Japan from the viewpoint of nations in the inner, outer, and expanding circles. JALT Journal, 28(1), 57-76.

Yonezawa, A., Akiba, H., \& Hirouchi, D. (2009) Japanese university leaders' perceptions of internationalization: The role of government in review and support. Journal of Studies in International Education, 13(2), 125-142.

Yphantides, J. (2013) Native-speakerism through English-only policies: Teachers, students and the changing face of Japan. In S. A. Houghton \& D. Rivers (Eds.), Native-Speakerism in Japan: Intergroup dynamics in foreign language education (pp. 207-216). Bristol: Multilingual Matters.

Robert J. Lowe is an English instructor at Rikkyo University. His research interests include taskbased learning, language and gender, and language ideology. He holds a diploma in TESOL, an MA in Applied Linguistics, and is currently studying towards a PhD in Applied Linguistics.

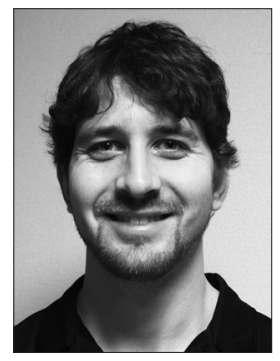

\section{EMAIL ADDRESS CHANGED?}

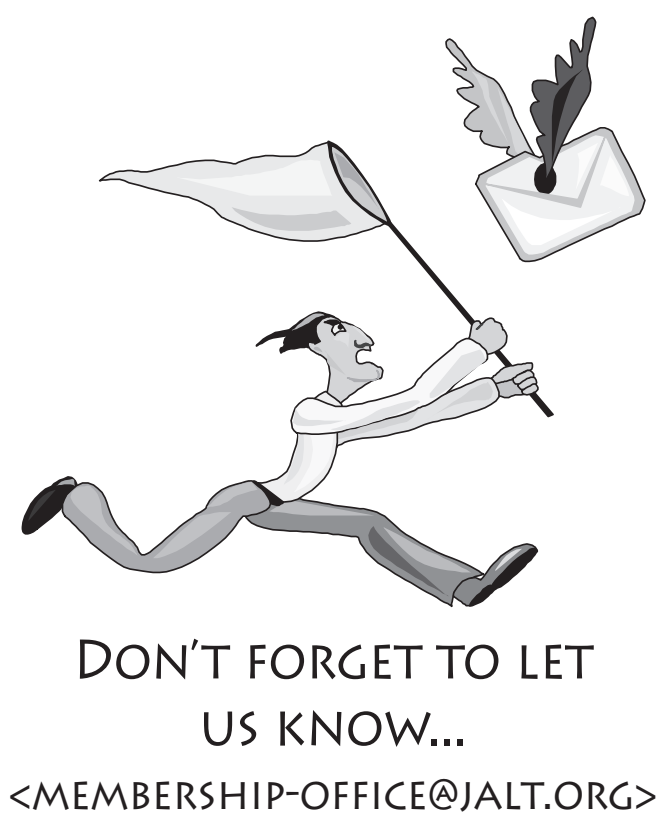

